\title{
Breves Notas sobre a Epistemologia de Friedrich A. von Hayek
}

\author{
Jorge Nogueira*
}

\begin{abstract}
Resumo: A abordagem epistemológica de Hayek aponta para a falibilidade, a ignorância e a fragmentação do conhecimento na sociedade. Sua epistemologia se estrutura de forma a revelar a impossibilidade da construção de ordens sociais desejáveis a partir da deliberada vontade humana dirigida a esse fim. A compreensão da epistemologia de Hayek contribui para rediscutir dogmas cristalizados nas áreas de ciências humanas e sociais, servindo de poderoso contraponto ao pensamento reinante no proscênio político, jurídico e acadêmico brasileiro.
\end{abstract}

Palavras-Chave: Limites do conhecimento. Falibilidade. Ignorância. Fragmentação do conhecimento. Racionalismo: evolucionista e construtivista. Evolucionismo cultural.

\section{Brief Notes on Friedrich A. von Hayek's Epistemology}

\begin{abstract}
Hayek's epistemological approach points to fallibility, ignorance and knowledge fragmentation in society. His epistemology is structured in order to reveal the impossibility of creating desirable social orders from a deliberate human will aimed at that purpose. The understanding of Hayek's epistemology contributes to the discussion about crystallized dogmas in the humanities and social sciences, serving as a powerful counterpoint to the predominant thought in the political, legal and academic Brazilian scenario.
\end{abstract}

Keywords: Limits to knowledge. Fallibility. Ignorance. Fragmentation of knowledge. Evolutionist and constructivist rationalism. Cultural evolutionism.

Classificação JEL: B53.

\footnotetext{
" Jorge Henrique de Saules Nogueira é advogado inscrito na OAB/DF e sócio do escritório Mendonça \& Nogueira Advogados Associados. Pós-Graduado em Ciência Política (UnB). Bacharel em Economia (UERJ) e em Direito (IESB/DF).

E-mail: jorge.saules@gmail.com
} 


\section{I - INTRODUÇÃo}

Thomas Sowell, professor de economia da Stanford University, apresenta o conceito epistemológico de visão como todo ato cognitivo prévio a qualquer raciocínio sistemático que poderia ser chamado teoria. É o sentimento de como o mundo funciona; é o ato cognitivo que constitui a base sobre a qual as teorias são construídas. As "visões são como mapas que nos guiam em um emaranhado de complexidades desconcertantes" 1 .

Para Sowell, as visões sociais diferem, basicamente, em suas concepções sobre a natureza do homem. Sob essa perspectiva, o autor divide as visões sociais entre "visão ilimitada" e "visão limitada".

Os adeptos da visão ilimitada creem que o gênio humano é capaz de dar uma resposta final aos males que assolam a humanidade. Assim, adotam uma postura teleológica na geração dos benefícios sociais que, segundo eles, só podem ser intencionalmente criados².

Diversamente, a visão limitada a que alude Sowell reconhece as limitações intrínsecas da natureza humana e, a partir dessas limitações, busca os melhores meios para produzir benefícios sociais desejados. Seus adeptos adotam uma postura procedimental, centrada nos processos sociais.

Sob as perspectivas traçadas por Sowell, o pensador austríaco nos apresenta uma visão de mundo limitada, calcada no liberalismo clássico. Essa visão foi, ao longo de sua profícua carreira acadêmica, sistematizada, aperfeiçoada e transformada em livros e conferências devotados a uma profunda análise dos princípios que devem reger uma sociedade livre com ênfase no arcabouço institucional capaz de estruturá-la.

\footnotetext{
${ }^{1}$ Tradução livre a partir do excerto: "Visions are like maps that guide us through a tangle of bewildering complexities". In: SOWELL, Thomas. A Conflict of Visions: Ideological Origins of Political Struggles. Revised Edition. Cambridge, MA. Basic Books, 2007.

${ }^{2}$ SOWELL. A Conflict of Visions: Ideological Origins of Political Struggles. p.24.
}

A despeito da diversidade temática que distingue a abordagem de Friedrich A. von Hayek (1899-1992), Henry Maksoud (19292014), no prefácio de Os Fundamentos da Liberdade, afirma que as obras do autor "constituem um só bloco de grande coerência intelectual"3. John Gray sugere que a coerência e a unidade do pensamento de Hayek é tributária de sua abordagem epistemológica, permeada por descrições sobre a estrutura da mente, da natureza e dos limites do conhecimento humano e do uso e do abuso da razão na vida em sociedade ${ }^{4}$.

Hayek compartilhava com os teóricos da Escola Austríaca de Economia a firme convicção de que falsas concepções epistemológicas facilitam a difusão e a consolidação de valores que põem em risco a liberdade do indivíduo na sociedade moderna ${ }^{5}$.

Em razão de seu iniludível comprometimento com a defesa da liberdade individual, Hayek passara a se interessar por questões epistemológicas que, em certa medida, oferecem o fio condutor para a compreensão das teses por ele expostas.

A abordagem epistemológica de Hayek tem por substrato sua particular noção sobre os limites do conhecimento humano e, em razão disso, sua ineficácia na construção de ordens sociais "desejáveis".

Nessa senda, o autor se ampara na perspectiva evolucionista inicialmente propugnada pelos escolásticos da Universidade de Salamanca $^{6}$ e, mais tarde, desenvolvida por

\footnotetext{
${ }^{3}$ Hayek, Friedrich A. Os Fundamentos da Liberdade. São Paulo. Ed. Visão, 1983, p. xx.

${ }^{4}$ GRAY, John. F. A. Hayek and the Rebirth of Classical Liberalism: A Bibliographical Essay. Literature of Liberty: A Review of Contemporary Liberal Thought. Cato Institute, vol. V, n. 4 (Winter 1982). Disponível em: <http://oll.libertyfund.org/?option=com_content\& task=view\&id=171\&Itemid=280\#sh01>.
}

${ }^{5}$ DE LA NUEZ, Paloma. La Política de La Libertad. Estudio del Pensamiento Político de F. A. Hayek. 2a Ed. Madrid: Unión Editorial, 2013.

${ }^{6}$ Para maiores detalhes sobre os autores escolásticos da Universidade de Salamanca vide o livro intitulado 
David Hume (1711-1776), Bernard de Mandeville (1670-1733) e Carl Menger (1840-1921).

O presente artigo apresenta noções básicas do desenvolvimento teórico de Hayek no campo da epistemologia ${ }^{7}$.

\section{II - A Coetaneidade entre Mente e Sociedade: As Normas de Conduta}

The Sensory Order: An Inquiry into the Foundations of Theoretical Pshychology (1952) constitui a obra chave para a compreensão da epistemologia de Hayek. Nessa obra, o autor ressalta o papel da ignorância e da falibilidade humana.

Hayek preconiza que o indivíduo possui a capacidade de ordenar e simplificar o universo complexo em que se encontra imerso, adaptando-se ao seu entorno, a despeito da irremediável ignorância que lhe é ínsita.

Nosso autor entende a mente humana a partir de uma abordagem kantiana, como algo criativo e não um mero receptor de sensações do mundo externo. Daí deduzir que, sendo a mente um órgão criativo, a ordem que alberga as experiências individuais será o produto da atividade criativa da mente. Em outras palavras, a ordem do mundo resulta do método através do qual as percepções sensoriais a concebe. Assim, só é possível atingir os propósitos humanos porque reconhecemos

The School of Salamanca, fruto da pesquisa realizada, sob a orientação de Hayek, pela especialista em latim e literatura, Marjorie Grice-Hutchinson (1908-2003), considerada, de acordo com Jesus Huerta de Soto uma das mais brilhantes alunas de Hayek. Ver: HUERTA DE SOTO, Jesus. A Escola Austríaca. Tradução de André Azevedo Alves. 2a Ed. São Paulo: Instituto Ludwig von Mises Brasil, 2010.

${ }^{7}$ Para seter uma claraideia da abordagem epistemológica de Hayek aplicada à teoria econômica, ver $O$ Uso do Conhecimento na Sociedade e, também, seu discurso proferido na ocasião da entrega do Prêmio Nobel de Economia, intitulado A Pretensão do Conhecimento, disponíveis respectivamente em: <http://www.mises. org.br/Article.aspx?id=1665 $>\mathrm{e}<\mathrm{http}$ ://www.mises.org. br/Article.aspx?id=222>. o mundo que habitamos como um mundo ordenado.

$\mathrm{O}$ indivíduo ordena seu mundo e se guia pela classificação de objetos e de acontecimentos realizados por seu próprio cérebro. Esse aparato de classificação não se revela como categoria fixa. Ao contrário, sujeita-se, portanto, à condição prevalecente no meio ao qual o indivíduo se insere .

Logo, a mente humana é produto do meio social. "O homem agiu antes de pensar, $e$ não entendeu antes de agir", afirma Hayek'. A mente humana não precede a sociedade. É ela, pois, coetânea à sociedade, sendo, portanto, influenciada pelo meio social, mas dotada de limitações substantivas para determiná-lo através de ações deliberadamente voltadas a propósitos específicos e previamente planejadas.

O homem aprendeu a partir da experiência, sem a preocupação de, aprioristicamente, lastrear suas ações em um processo mental organizado (raciocínio). O aprendizado, assim, consiste na transmissão e no aperfeiçoamento de práticas que acabam por se impor ao beneficiarem, de alguma forma não premeditada, o agrupamento social ${ }^{10}$. Tentativas, erros e acertos deram a tônica das ações interindividuais e institucionais que plasmaram a civilização ocidental contemporânea.

Daí concluir-se que a mente e a sociedade se desenvolvem concomitantemente e não sucessivamente. É a mente humana, então, produto de uma evolução cultural.

A perspectiva do evolucionismo cultural perpassa toda a obra do autor ${ }^{11}$. Hayek

\section{${ }^{8}$ DE LA NUEZ. La Política de La Libertad. Estudio del Pensamiento Político de F. A. Hayek.}

${ }^{9}$ HAYEK, Friedrich A. Direito, Legislação e Liberdade: uma nova formulação dos princípios liberais de justiça e economia política. Vol. I. São Paulo: Ed. Visão, 1985, p. 13.

${ }^{10}$ HAYEK. Direito, Legislação e Liberdade: uma nova formulação dos princípios liberais de justiça e economia política. p. 13.

${ }^{11} \mathrm{~A}$ perspectiva evolucionista será apresentada com mais detalhes na Seção 2.6, em virtude da importância do tema no pensamento de Hayek. 
alude a uma herança cultural consistente num complexo de práticas e normas de conduta que conduziram o agrupamento humano ao êxito, mas cujo resultado ninguém seria capaz de prever ou formular em termos racionais. Tais normas, no entanto, desenvolveram-se porque garantiam a sobrevivência dos grupos que a praticavam e não porque se direcionavam à consecução de uma finalidade previamente conhecida.

As práticas e normas de conduta originárias têm, por assim dizer, dois atributos os quais o autor enfatiza:

I) As normas de conduta são observadas, na prática, pelo indivíduo que age, sem serem conhecidas sob uma forma expressa (verbal ou escrita) e;

II) As normas de conduta são observadas porque dotam o grupo de maior força frente aos desafios a que estão expostos.

A conclusão é que as normas que regem a conduta humana são aceitas porque sua observância implica certas consequências. Contudo, essas normas não são observadas com o intuito deliberado de se produzir tais ou quais consequências, cujo teor é indiferente àqueles que simplesmente agem, assim o fazendo em razão de seu elevado grau de abstração. Para Hayek, este é um problema que observamos mais de perto no aprendizado da linguagem pelas crianças, capazes muitas vezes de compor corretamente expressões de grande complexidade que nunca ouviram antes, mas que também ocorre em domínios como o da conduta, da moral e do direito, e na execução de muitas tarefas, em que somos orientados por normas que sabemos observar, mas somos incapazes de verbalizar.

O importante é que todo homem, tendo sido criado numa determinada cultura, perceberá ser portador de normas ou poderá descobrir que age de acordo com normas - e, do mesmo modo, reconhecerá estarem as ações dos demais em conformidade ou não com normas $^{12}$.

12 HAYEK. Direito, Legislação e Liberdade: uma nova formulação dos princípios liberais de justiça e economia política. p. 15-16.
No entanto, a perspectiva evolucionista de Hayek inclina-o a rejeitar a noção de que a aceitação de tais normas esteja gravada na natureza humana. Para ele, trata-se apenas de "uma herança cultural que tende a ser relativamente constante, sobretudo porque não são verbalizadas $[. . .]^{\prime \prime 13}$.

\section{III- Os Limites do Conhecimento: FALIBILIDAde, IgNORÂNCIA E FRAGMENTAÇÃo}

Hayek afirma que a mente humana é dotada de limitações intrínsecas. Qualquer aparato de classificação (no nosso caso, o cérebro) deve possuir estrutura em nível mais elevado do que possui o objeto que se pretende classificar. Dessa forma, a mente não pode situar-se por cima de si mesma para contemplar suas próprias operações. Hayek admite, no entanto, que é possível apreender o funcionamento do cérebro em termos gerais, o que denomina " $e x$ plicações de princípios", o oposto da apreensão de explicações detalhadas de como o cérebro funciona em circunstâncias particulares.

Essa constatação se revela extremamente importante quando se busca compreender o significado da liberdade em Hayek. Porquanto a mente humana possui insuperáveis limitações constitutivas, a ordem social não pode ser produto de uma inteligência reitora e planificadora. Não é possível governar com precisão a mente humana, a partir de explicações detalhadas de como ela deve funcionar em circunstâncias particulares de tempo e lugar. Por conseguinte, não é possível modelar todos os aspectos da vida social de acordo com um plano pré-concebido por essa mesma inteligência ordenadora.

A propósito, De La Nuez sugere que o problema do socialismo - e, acrescento, do dirigismo jurídico em suas mais variadas vertentes - é também um problema epistemológico ${ }^{14}$.

\footnotetext{
${ }^{13}$ Idem. Ibidem, p. 16.

${ }^{14}$ DE LA NUEZ. La Política de La Libertad. Estudio del Pensamiento Político de F. A. Hayek.
} 
As limitações constitutivas da mente humana implicam limitações ao conhecimento. A falibilidade e a irremediável ignorância dos indivíduos a que reporta Hayek concernem à "maioria dos fatos particulares que determinam as ações de todos os diversos membros de uma socieda$d e^{\prime \prime 15}$.

Essa óbvia - e até mesmo intuitiva constatação impõe limites ao que se pode dizer ou fazer em relação aos processos sociais.

Hayek observa que, nas pequenas sociedades primitivas, os eventos a que os indivíduos se defrontam em suas atividades cotidianas são bastante semelhantes para todos os integrantes do grupo. Assim, apenas os pequenos grupos que guardam características semelhantes seriam capazes de um conhecimento relativo sobre as mesmas circunstâncias particulares ${ }^{16}$.

Nas sociedades avançadas, o cenário é bastante diverso. Nelas, milhões de indivíduos interagem diuturnamente. $\mathrm{O}$ conhecimento está disperso e cada indivíduo só é capaz de deter uma parcela ínfima do conhecimento disponível. Por essa razão, cada qual desconhece a maioria dos fatos sobre os quais repousa o funcionamento da sociedade. Daí Hayek afirmar que é a fragmentação do conhecimento do homem em sociedade que constitui "o traço distintivo de todas as civilizações avançadas" 17.

Sob essa perspectiva, Hayek aduz que:

A civilização se funda no fato de nos beneficiarmos todos de conhecimento que não possuímos. E uma das maneiras porque a civilização nos ajuda a superar esse limite da extensão do conhecimento individual é a subjugação da ignorância, não mediante a aquisição de mais conhecimento, mas mediante a utilização do conhecimento que está e permanece amplamente disperso entre os indivíduos ${ }^{18}$.

\footnotetext{
${ }^{15}$ HAYEK. Direito, Legislação e Liberdade: uma nova formulação dos princípios liberais de justiça e economia política. p. 7.

${ }^{16}$ Idem. Ibidem, p. 8-9.

${ }^{17}$ Idem. Ibidem, p. 9.

${ }^{18}$ Idem. Ibidem, p. 10.
}

O benefício extraído do conhecimento que um indivíduo possa adquirir não é tão significativo quanto o benefício que se extrai da miríade de conhecimentos dispersos na sociedade.

A fragmentação do conhecimento liberta o indivíduo, ofertando-lhe opções mais amplas que a de sua mera subsistência.

\section{IV-Conhecimento e Ciência: Desmascarando o MaINSTREAM ACADÊMICO}

Aqui, um sério problema se impõe. A falibilidade e a irremediável ignorância humana sobre fatos particulares são descartadas com impressionante frequência nos programas de pesquisas em ciências humanas e sociais.

O raciocínio que daí deriva prossegue baseado na falsa hipótese de que a mente do cientista é capaz de abarcar a totalidade dos fatos particulares que determinam os processos que se desenvolvem na sociedade. Da análise, cuja ignorância sobre fatos particulares fora abandonada $a b$ initio, resulta a falsa percepção de que é possível construir ordens sociais "desejáveis".

De acordo com Hayek, uma das principais teses que confere suporte epistemológico ao seu pensamento refere-se ao fato de que grande parte das normas de conduta, que orientam as ações dos indivíduos e as instituições decorrentes dessas mesmas normas, "constituem ajustamentos à impossibilidade em que se encontra qualquer pessoa de considerar conscientemente todos os fatos particulares que integram a ordem da sociedade" 19 .

A constituição da mente humana impõe limites ao conhecimento de particularidades dispersas na vida social, os quais, para Hayek, a ciência é incapaz de superar. Entretanto, o autor aponta que a confiança irrestrita nos poderes da ciência oblitera a visão do homem

\footnotetext{
${ }^{19}$ Idem. Ibidem, p. 8.
} 
no que tange aos limites impostos ao seu conhecimento. A enunciação de relações determinantes como função de algumas poucas e determinadas variáveis criou a ilusão de que se pode realizar o mesmo frente aos fenômenos complexos. E o Direito lida com fenômenos complexos.

De acordo com Hayek:

nem a ciência nem qualquer outra técnica conhecida nos permite superar o fato de que mente alguma, e, portanto, nenhuma ação deliberadamente orientada, pode levar em conta todos os fatos específicos conhecidos por alguns homens, mas não conhecidos, em sua totalidade, por ninguém em particular $^{20}$.

Em relação aos fenômenos complexos, o poder da ciência é limitado. O máximo que se pode obter com a aplicação de teorias científicas à hipercomplexidade que caracteriza a sociedade moderna é a apreensão do caráter geral de certos fenômenos.

Reivindicar previsões ou explicações pormenorizadas e completas sobre fenômenos sociais constitui erro essencial sobre o poder da ciência.

\section{V- Duas Escolas de Pensamento: Racionalismo Construtivista versus RaCiOnAlismo Evolucionista}

A perspectiva epistemológica de Hayek contraria concepção diversa que admite a existência de uma mente independente, que se posiciona fora da ordem da natureza e, ao mesmo tempo, busca guiar e capacitar o homem para o planejamento das instituições da sociedade e da cultura ${ }^{21}$. É contra essa concepção, por ele denominada racionalismo construtivista, que o autor desfere substantivas críticas.

Hayek identifica duas concepções teóricas diversas sobre a formação das insti-

\footnotetext{
${ }^{20}$ Idem. Ibidem, p. 11.

${ }^{21}$ Idem. Ibidem, p. 12.
}

tuições sociais. Tais concepções plasmaram duas escolas de pensamento, cujas proposições remetem, de um lado, à noção de racionalismo construtivista e, de outro lado, à de racionalismo evolutivo, equivalentes respectivos do racionalismo ingênuo e crítico de Karl Popper (1902-1994).

O racionalismo construtivista ou ingênuo está associado à escola de pensamento francesa.

Segundo Hayek, a concepção construtivista, de base especulativa, tem por fundamento servir como guia do indivíduo e da sociedade a partir da crença no poder ilimitado da razão, eliminando de seus pontos de vista tudo aquilo que se apoie na tradição. É a personalização do Iluminismo francês, calcado no racionalismo cartesiano, cujos expoentes estão entre os Enciclopedistas, os Fisiocratas, Jean-Jacques Rousseau (1712-1778) e Nicolas de Condorcet (1743-1794). Para o autor, essa linha de pensamento é utópica, além de ter fornecido as bases filosóficas, políticas e jurídicas das mais variadas espécies de totalitarismos que singraram o século XX.

Já o racionalismo evolutivo ou crítico liga-se à escola anglo-saxônica, de índole empirista e assistemática. Para Hayek, a abordagem evolucionista funda-se na interpretação de tradições e instituições que surgiram de forma espontânea, inspiradas na jurisprudência do direito consuetudinário. Essa vertente teve início com os filósofos morais escoceses, entre eles David Hume, Adam Smith (1723-1790) e Adam Ferguson (17231816), e com seus contemporâneos ingleses Josiah Tucker (1713-1799), Edmund Burke (1729-1797) e William Paley (1743-1805).

É preciso ressaltar, no entanto, que o pensador austríaco entende que a diferença de enfoque dessas duas escolas de pensamento não se restringe a uma mera questão de nacionalidades, contrapondo britânicos a franceses. As abordagens de franceses como Montesquieu (1689-1755), Benjamin Constant (1767-1830) e Alexis de Tocqueville (18051859) estiveram mais próximas da linha de pensamento britânica, enquanto as de ingle- 
ses como Thomas Hobbes (1588-1679) e Jeremy Bentham (1748-1832) se aproximaram da francesa ${ }^{22}$.

\section{V.1 - O Racionalismo Construtivista ou Ingênuo}

O filósofo René Descartes (1596-1650) traçou as linhas básicas do modus operandi que Hayek denominara racionalismo construtivista. Embora Descartes tenha assentado como objetivo imediato estabelecer critérios para a verdade de proposições lógicas, foram seus seguidores que delas extraíram conclusões aplicáveis à análise das questões morais e sociais, ao fazer uso dos critérios estabelecidos pelo filósofo francês para o julgamento da adequação e justificação das práticas e condutas.

Segundo Hayek, "[a] "dúvida radical" de Descartes o fez recusar a aceitar como verdadeiro tudo o que não pudesse ser logicamente deduzido de premissas explícitas, claras e distintas" 23 . O resultado foi a invalidação de todas as normas de conduta que não se enquadrassem nesse figurino lógico, única base válida para o julgamento das ações. Sob esse aspecto, Hayek reconhece que Descartes tentasse escapar dessa conclusão lógica atribuindo tais normas de conduta aos desígnios de Deus. Com esse expediente, Descartes, em um primeiro momento, suprime a metafísica de seu sistema de pensamento, ao mesmo tempo em que dela se socorre para livrá-lo das conclusões a que, inevitavelmente, se defrontaria: a negação da tradição, cara àquele pensador.

Seus seguidores, embevecidos com os critérios cartesianos, levaram sua teoria às últimas consequências ao rejeitarem como "mera opinião" o desfecho por ele proposto, pois não mais lhes parecia ser justificável em bases racionais a aceitação dos desígnios divinos como critério para determinação da conduta.

\footnotetext{
${ }^{22}$ Idem. Ibidem, p. 54-57.

${ }^{23}$ Idem. Ibidem, p. 4.
}

A ação verdadeira passou a ser toda aquela que fosse demonstrada e determinada pela razão, definida a partir de dedução lógica baseada em premissas explícitas. A partir desse ponto de vista, diversas concepções filosóficas passaram a pugnar que as instituições culturais úteis à civilização resultam da criação ou do aperfeiçoamento deliberado do homem, cuja racionalidade se exprimira pari passu a partir de planos pré-concebidos. Estruturas estabelecidas pela tradição, tais como moral, religião, linguagem, escrita, moeda, mercado e direito, passam a ser entendidas como instituições deliberadamente criadas ou aperfeiçoadas pela ação planejada do homem. De acordo com Hayek, "essa se tornou a atitude filosófica característica do construtivismo cartesiano, com seu desprezo pela tradição, o costume e a história em geral" 24 .

Descartes abriu caminho para um séquito de "engenheiros sociais" que intentam moldar a sociedade aos preceitos contidos em seus programas de pesquisa, não raro permeados por preconceitos ideológicos.

Hayek aponta a falsidade da ideia segundo a qual o homem conseguiu dominar o meio através de sua capacidade cognitiva. De acordo com Hayek,

simplesmente não é verdade que nossas ações devem sua eficácia apenas ou sobretudo ao conhecimento que somos capazes de verbalizar e que pode, portanto, constituir as premissas explicitas de um silogismo. Muitas instituições da sociedade que são condições indispensáveis para a consecução de nossos objetivos conscientes resultaram, na verdade, de costumes, hábitos ou práticas que não foram inventados nem são observados com vista a qualquer propósito semelhante. Vivemos numa sociedade em que podemos orientar-nos com êxito e em que nossas ações têm boas probabilidades de atingir seu objetivo, não só porque nossos semelhantes são norteados por objetivos conhecidos ou por relações conhecidas entre meios e fins, mas porque eles são também limitados por normas cujo propósito ou origem muitas vezes-

\footnotetext{
${ }^{24}$ Idem. Ibidem, p. 4.
} 
desconhecemos e das quais, frequentemente, ignoramos a própria existência ${ }^{25}$.

Para Hayek, o homem não persegue tão somente fins, mas também - e principalmente - objetivos e normas. O homem

alcança seus objetivos não por conhecer as razões pelas quais deve observar as normas que observa, nem por ser capaz de dar expressão verbal a todas elas, mas porque seu pensamento e ação são orientados por normas que, por um processo de seleção, evoluíram na sociedade em que ele vive e que, assim, são produto da experiência de gerações ${ }^{26}$.

O racionalismo construtivista, de cunho cartesiano, é reducionista, pois pressupõe onisciência no tocante aos fatos particulares extraídos das relações interindividuais travadas na sociedade.

Obviamente, tamanha empreitada não é dada a qualquer indivíduo ou grupo conhecer. Entretanto, o que parece ser uma clara constatação é sempre convenientemente esquecido quando se pretende explicar e influenciar os processos sociais.

\section{V.2 - O Racionalismo Evolucionista ou Crítico}

Os sofistas do século $\mathrm{V}$ a. c distinguiram a estrutura das atividades humanas a partir de dois fenômenos modernamente descritos como fenômenos naturais e fenômenos artificiais.

Para Hayek, desde então, muita confusão foi gerada a partir da dicotomia que contrapunha a noção de natural e artificial para classificar os objetos ou eventos que existem, respectivamente, de forma independente ou em função da ação humana.

A partir da obra de Sten Gagnér (19212000), intitulada Studien zur Ideengeschichte der Gesetzgebung (1960), Hayek ensina que, no

\footnotetext{
${ }^{25}$ Idem. Ibidem, p. 5-6.

${ }^{26}$ Idem. Ibidem, p. 6.
}

século II, o gramático latino, Aulo Gélio (125180), traduziu os termos gregos physei e thesei por naturalis e positivus, a partir dos quais se deriva a designação de dois tipos de direito: o direito natural e o direito positivo. Assim, o autor sugere que as dissensões existentes entre ambos remonta à falsidade da dicotomia empreendida pelos gregos e à tradução inexata trazida à baila pelos pensadores latinos.

A dicotomia proposta pelos gregos - e reproduzida pelos pensadores latinos - fora objeto de análise dos escolásticos medievais que, já no século XII, haviam chegado perto do reconhecimento de uma categoria intermediária de fenômenos resultantes de ação, mas desprovidos de deliberada intenção humana. Desde então, para os escolásticos a expressão naturalis passou a designar tudo o que não correspondesse à criação humana ou que não estivesse sujeito à sua criação intencional.

Hayek aponta que a expressão naturalis consubstanciava um termo técnico utilizado pelos últimos escolásticos espanhóis do século XVI "para designar fenômenos sociais que não fossem deliberadamente moldados pela vontade humana"27.

Bernard de Mandeville, em sua obra Fábula das Abelhas (1728), aponta explicitamente uma maneira de resolver o dilema, alertando para a existência de um tertium genus que se fixa na ausência de elemento volitivo da ação humana ${ }^{28}$.

Assim, Hayek rejeita a dicotomia grega e passa a defender uma visão tricotômica dos fenômenos naturais e artificiais, incluindo, ao lado deles, um fenômeno intermediário que torna possível a criação de instituições pelo homem sem que, necessariamente, as crie

\footnotetext{
${ }^{27}$ Idem. Ibidem, p. 18.

${ }^{28}$ Nesse ponto, Iorio afirma a influência de Bernard de Mandeville em David Hume, Adam Smith, Edmund Burke e, no século seguinte, em Savigny, que recebeu a influência de Mandeville por intermédio das escolas "historicistas" alemãs. Este, por sua vez, influenciou Carl Menger, o fundador da Escola Austríaca de Economia. Ver: IORIO, Ubiratan. Economia e Liberdade. A Escola Austríaca e a Economia Brasileira. 2a. Ed. São Paulo: Ed. Forense Universitária, 1997.
} 
com a intenção deliberadamente dirigida a fins específicos.

\section{VI - O Evolucionismo Cultural DE HAYEK}

A perspectiva evolucionista parte da percepção de que algumas estruturas regulares da sociedade e a própria sociedade não surgiram a partir de um objetivo consciente e deliberado da ação humana.

Hayek enfatiza que as sociedades foram se transformando através do tempo, desde as sociedades tribais primitivas até as modernas e complexas sociedades, por meio da ação humana, mas não pela ação humana previamente planejada. Logo, as sociedades surgem por um processo de tentativa e erro e de estabilização.

Longe de ter-se plasmado como produto da razão, a sociedade surgiu de um processo de modificações lentas e constantes. Em outras palavras, surgiu de um processo evolutivo que, em teoria social, antecede ao evolucionismo biológico de Charles Darwin $(1809-1882)^{29}$.

A abordagem evolucionista desenvolvida, inicialmente, pelos escolásticos da Universidade de Salamanca, foi sufocada nos séculos XVI e XVII pela ascensão do racionalismo construtivista que operou a desconstrução do significado do termo razão e, consequentemente, da expressão direito natural. A razão deixa de ser entendida como "a capacidade da mente de distinguir entre o bem e o mal, ou seja, entre o que estava ou não de acordo com regras estabelecidas", para significar "a capacidade de construir normas por dedução, a partir de premissas explícitas" ${ }^{\prime \prime}$. Em razão dessa inversão, a concepção de Justiça - entendida por Aristóteles (384-322 a.C.) como a virtude cardeal

29 HAYEK. Direito, Legislação e Liberdade: uma nova formulação dos princípios liberais de justiça e economia política. p. 21.

${ }^{30}$ Idem. Ibidem, p. 18-19.
- passa a ser vilipendiada em nome de um coletivismo rasteiro que a pretexto de promovê-la acaba por soterrá-la, levando a reboque a liberdade individual.

Por conseguinte, não mais se atribui à razão o papel de intérprete das normas estabelecidas. A razão passa a ser, então, o fundamento de validade do direito natural. Nesse ponto, Hayek faz expressa referência ao direito natural de Hugo Grotius (1583-1645), calcado que era em uma filosofia especulativa e racionalista que, inclusive, na opinião do autor, tangencia a concepção positivista do direito.

Para Grotius, a lei pode ser produzida pela razão ou, pelo menos, pode ser por ela justificada, assim como seus futuros oponentes positivistas a conceberam. A diferença reside no fato de que o direito natural de Grotius não admite que a lei possa ser logicamente deduzida de premissas construídas " $a$ priori".

A despeito dessa recaída operada por Grotius, a perspectiva evolucionista, iniciada pelos escolásticos medievais, ressurgiu a partir das obras de Bernard de Mandeville e de David Hume, ambas inspiradas na interpretação do direito consuetudinário inglês, proposta por Matthew Hale (1609-1676).

A elaboração do evolucionismo cultural foi realizada, primeiramente, no campo da economia, durante a segunda metade do século XVIII, pela pena dos filósofos da moral escoceses Adam Smith e Adam Ferguson. Conquanto não tenha se apresentado de forma sistematizada, Edmund Burke desenvolveu-a na seara da teoria política. A escola histórica alemã de linguística e de direito dotou a teoria da evolução social de novos contornos, principalmente, por intermédio dos acadêmicos de Hannover, Ernst Brandes (17581810) e August Wilhelm Rehberg (1757-1836). Com Wilhelm von Humboldt (1767-1835) e Friedrich Carl von Savigny (1779-1861) foi concretizada sua sistematização em torno dos fenômenos sociais. A reintrodução da perspectiva evolucionista na Inglaterra se deu por influência de um discípulo de Savigny, Sir Henry Maine (1822-1888). 
Por fim, a mais completa reafirmação do evolucionismo cultural foi desenvolvida, segundo Hayek, por Carl Menger, fundador da Escola Austríaca de Economia ${ }^{31}$.

Diante desse cenário, é preciso esclarecer que, diferentemente do que afirmam autores como Salama e Mendes ${ }^{32}$, a obra de Hayek, em sua faceta jurídica, não é jusnaturalista. Seu agnosticismo o impede de aceitar que "o direito seja produto do desígnio de uma inteligência humana, ou produto do desígnio de uma mente sobre-humana".

Assim, Hayek representa uma terceira concepção jurídica - não identificada com o juspositivismo e tampouco com o jusnaturalismo - que bem poderia ser denominada teoria evolucionista do direito.

\section{VI.1 - Evolucionismo Cultural não se confunde com Darwinismo Social}

Hayek atribui a dois recorrentes equívocos a desconfiança que cerca a teoria da evolução social.

O primeiro deles refere-se à suposta apropriação de conceitos do campo da biologia e sua consequente aplicação às ciências sociais.

Sob esse aspecto, Hayek inverte a noção de que o evolucionismo cultural tomou de empréstimo os conceitos biológicos desenvolvidos por Charles Darwin. O que ocorreu, de fato, foi precisamente o contrário. Darwin foi quem aplicou à biologia os conceitos apreendidos da análise das estruturas sociais, tais como a linguagem, a moral, a moeda e o direito. Conforme aduz nosso autor, "um teórico social do século XIX que precisasse recorrer a Darwin para compreender a ideia de evolução não era digno de respeito"33.

\footnotetext{
${ }^{31}$ Idem. Ibidem, p. 20.

32 SALAMA, Bruno \& MENDES, Lucas. Direito como Liberdade. Ordem Livre, 2010. Disponível em: <http:// ordemlivre.org/posts/direito-como-liberdade>. Acesso em: 29/3/2014.

33 HAYEK. Direito, Legislação e Liberdade: uma nova formulação dos princípios liberais de justiça e economia política. p. 21.
}

A esse propósito, Hayek reproduz, em Direito, Legislação e Liberdade, excerto da lavra de Sir Frederick Pollock (1845-1937), extraído de Oxford Lectures and Others Discourses (Londres, 1890), que diz:

A doutrina da evolução nada mais é que o método histórico aplicado aos fatos da natureza; o método histórico nada mais é que a doutrina da evolução aplicada às sociedades e instituições humanas. Ao criar a filosofia da história natural (pois não merece título menor a ideia que transformou o conhecimento da natureza orgânica de uma infinidade de fragmentos em um todo continuo), Charles Darwin trabalhava no mesmo espírito e visando ao mesmo fim que os grandes estudiosos do direito público, que, tão pouco atentos ao campo de Darwin quanto este ao deles, construíram pelo paciente estudo do fato histórico a base de uma filosofia da política e do direito sólida e racional. Savigny, a quem ainda não conhecemos ou reverenciamos o suficiente, ou o nosso próprio Burke, a quem conhecemos ou reverenciamos, mas a quem nunca poderemos reverenciar o bastante, foram darwinistas antes de Darwin. Até certo ponto, o mesmo pode ser dito do grande francês Montesquieu, cujo espírito inconstante mas luminoso se perdeu numa geração de formalistas ${ }^{34}$.

Para Hayek, a dissociação do evolucionismo cultural do que se convencionou chamar "darwinismo social" consiste em um erro essencial levado a cabo pelos teóricos desta corrente de pensamento.

o erro do "darwinismo social" foi tomar por objeto a seleção de indivíduos e não a seleção de instituições e práticas; a seleção de aptidões inatas dos indivíduos e não a daquelas culturalmente transmitidas. Mas, embora o esquema da teoria darwinista se aplique a estas últimas de forma limitada, e seu uso literal conduza a graves distorções, o conceito básico de evolução ainda permanece o mesmo em ambos os campos ${ }^{35}$.

\footnotetext{
${ }^{34}$ Idem. Ibidem, p. 22.

${ }^{35}$ Idem. Ibidem, p. 22.
} 
O segundo equívoco mencionado pelo autor passa pela percepção errônea de que o evolucionismo cultural se escora em "leis de evolução".

A evolução cultural sustentada por Hayek não se adstringe a uma sequência de etapas ou fases passíveis de serem enunciadas ou previstas. Pelo contrário. Hayek entende que a evolução cultural consiste em um processo, cuja complexidade envolvida, resultante da enormidade de atos e fatos extremamente específicos, impede-nos de emitir previsões consistentes em relação ao futuro.

\section{VII - CONCLUSÃo}

Por influência dos escolásticos tardios da Universidade de Salamanca e do liberalismo escocês, a obra de Hayek adota uma perspectiva evolucionista cuidadosa e consistentemente estruturada numa base epistemológica que aponta para a falibilidade, a ignorância humana e a fragmentação do conhecimento na sociedade.
Essa estruturação implica a impossibilidade da construção de uma ordem social livre a partir da deliberada vontade humana dirigida a fins específicos, à maneira dos anseios que movem os planejadores e os "engenheiros sociais" que hoje abarrotam as universidades brasileiras.

A apreensão da epistemologia de Hayek se presta, portanto, a contribuir para a rediscussão de dogmas cristalizados, servindo como forte contraponto teórico à homogeneidade do tíbio proselitismo político propagandeado em nossas universidades. Daí resulta a relevância de estudar a rica abordagem formulada por Hayek. Uma abordagem calcada na contenção do poder do Estado frente a sempre desejada liberdade do indivíduo na sociedade.

A compreensão da abordagem epistemológica de Hayek constitui instrumento útil a habilitar o indivíduo a imunizar-se contra as investidas racional-construtivistas que se reproduzem com inaudita virulência, apesar das notórias - e até ingênuas - inconsistências que as qualificam. cos 


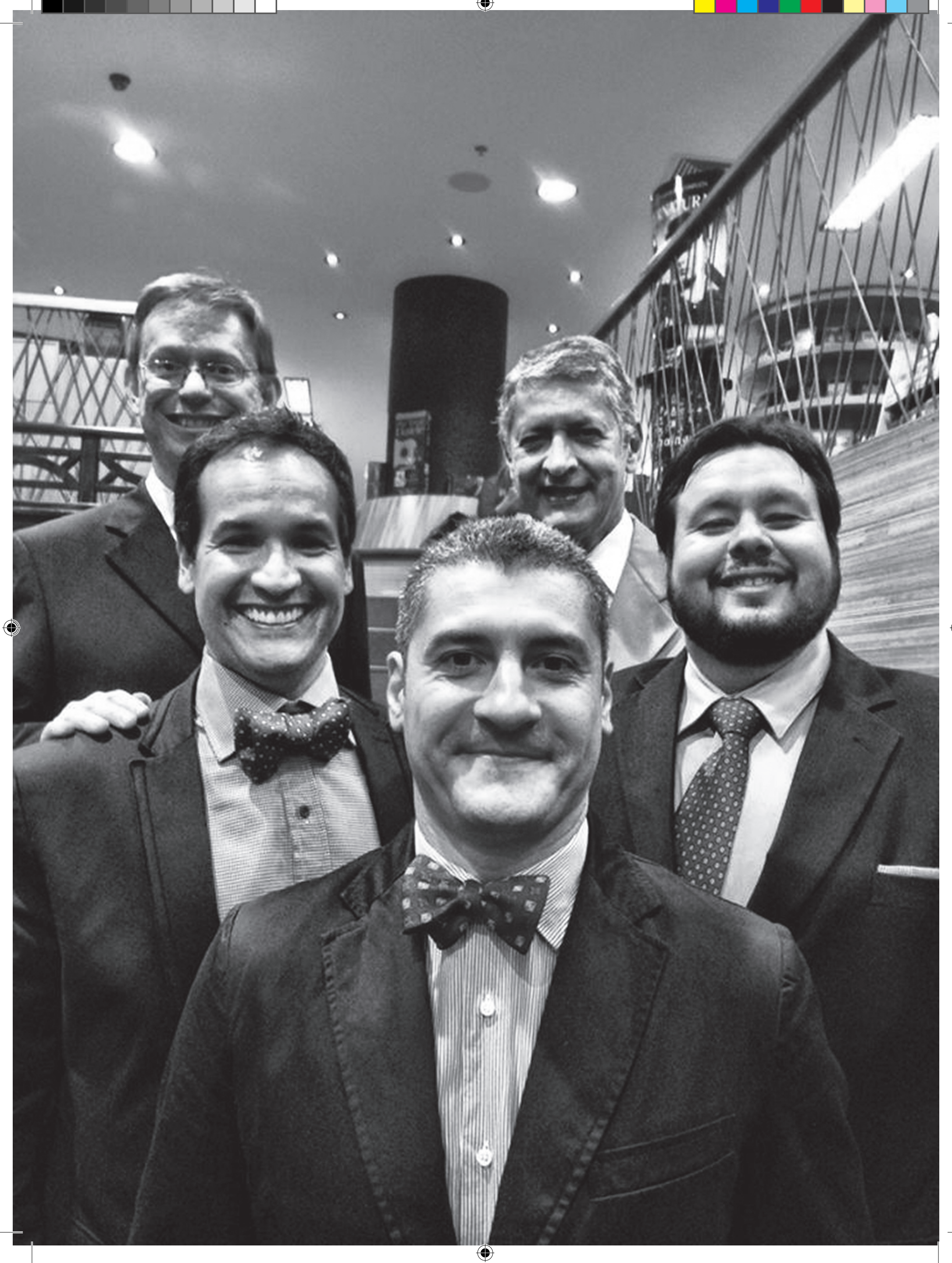


MISES: Revista Interdisciplinar de Filosofia, Direito e Economia

ISSN 2318-0811

Volume IV, Número 1 (Edição 7) Janeiro-Junho 2016: 43-68

\title{
Pontos de Contato Entre Escola Austríaca e Cristianismo Bíblico no Debate Sobre Preço Justo*
}

\author{
Yago Martins ${ }^{* *}$
}

\begin{abstract}
Resumo: A temática do preço justo é objeto de discussão tanto na tradição do pensamento cristão, quanto nas abordagens axiológicas proporcionadas pela Escola Austríaca de Economia. Por intermédio da apresentação e discussão da perspectiva bíblica a respeito do preço justo, bem como de reflexões de autores representativos do pensamento econômico escolástico e da Escola Austríaca de Economia, abordo e analiso os pontos de contato entre a Escola Austríaca e o Cristianismo Bíblico a respeito dessa temática.
\end{abstract}

Palavras-Chave:Preço Justo. Economia Austríaca. Pensamento Econômico Escolástico.

\section{Contact Points Between the Austrian School and Biblical Christianity in the Debate Concerning Fair Prices}

\begin{abstract}
The subject of fair prices is addressed by the tradition of Christian thought and by the axiological approaches provided by the Austrian School of Economics. Through the presentation and discussion of the biblical perspective regarding fair prices, as well as through reflexions by prominent authors of scholastic economic thought and the Austrian School of Economics, I address and analyze the contact points between the Austrian School and biblical Christianity about the subject.
\end{abstract}

Keywords: Fair Price. Austrian Economics. Scholastic Economic Thought.

Classificação JEL: B11, B53, Z12.

\begin{abstract}
"Apresentado na Faculdade Teológica Unida no dia 7 de dezembro de 2015 sob o título "Religião e Mercado" e no Núcleo de Estudos em Cosmovisão Cristã no dia 27 de agosto de 2016, com o título "Em busca do preço justo". Uma versão preliminar foi publicada em Teologia Brasileira n. 52, ano 2016, disponível online, e chegou a ser o artigo mais lido no site da revista. Agradeço às leituras e contribuições de André Venâncio, David Koyzis, Fernando Henrique, Marcelo Berti e Ubiratan Jorge Iorio, além dos comentários enriquecedores de alunos durante as palestras e de leitores da primeira versão publicada. Obviamente, as posições aqui tratadas são de inteira responsabilidade do autor.
\end{abstract}

* Yago Martins é bacharel em Teologia pela Faculdade Teológica Sul-Americana (Londrina/PR), pós-graduando em Escola Austríaca de Economia pelo Centro Universitário Ítalo Brasileiro, em parceria com o Instituto Ludwig von Mises Brasil (São Paulo/SP) e estudante do Sacrae Theologiae Magister (Th.M) em Teologia Sistemática do Instituto Aubrey Clark (Fortaleza/CE). Autor de Você não precisa de um chamado missionário e Faça discípulos ou morra tentando, ambos pela Editora Concílio. Professor residente no Seminário e Instituto Bíblico Maranata, uma das instituições de ensino teológico mais respeitadas do Nordeste, coordenador do Núcleo de Estudos em Cosmovisão Cristã e pastor auxiliar na Igreja Batista Maanaim. Trabalha desde 2009 com evangelismo de estudantes na Missão GAP, sendo presidente do conselho diretor desde 2016. Organiza anualmente o Fórum Nordestino de Cosmovisão Cristã. Atuante na popularização de teologia na internet, fez parte do blog Voltemos ao Evangelho, fundou o ministério Cante as Escrituras, produziu de forma independente o webdocumentário Ministérios Fracassados e hoje apresenta o programa Dois Dedos de Teologia, o maior canal teológico do Youtube Brasil. É casado desde 2014 com Isa Cavalcante, ao lado de quem grava alguns vídeos e viaja pelo país palestrando e pregando em igrejas de várias denominações.

E-mail: yagocmartins@gmail.com 
"Vão também trabalhar na vinha, e eu lhes pagarei o que for justo[...]. Você não concordou em trabalhar por um denário? [...] Não tenho o direito de fazer o que quero com o meu dinheiro?" - Mateus 20.1-15

\section{I - INTRODUÇÃO}

Há uma famosa história, possivelmente apócrifa, sobre um sapateiro que, abordando Martinho Lutero (1483-1546), perguntou como ser um bom cristão em sua profissão. "Devo desenhar cruzes nos sapatos que faço?", teria questionado o homem, curioso sobre como viver o cristianismo na vida profissional. A resposta de Lutero era que seu cristianismo seria vivido não em adicionar elementos religiosos ao visual dos calçados. Seu ensinamento foi: "Faça um bom sapato $e$ venda por um preço justo" ${ }^{1}$. Esta história costuma ser contada para ilustrar sobre a necessidade de viver o cristianismo em todas as áreas da vida, mas ela também evoca uma questão diferente. O que define um preço justo? O que faz com que a equivalência financeira na troca de um produto seja injusta? E se salários são nada mais que preços para um serviço, o que faz com que as precificações salariais sejam também injustas?

"Sempre que o intercâmbio econômico estava sendo discutido", Odd Langholm observa sobre os cristãos medievais, "um dos princípios fundamentais [...] era que o trabalho honesto merece sua recompensa material" ${ }^{2}$. Essa preocupação tem cercado muitos cristãos

${ }^{1}$ Registre-se que é impossível encontrar qualquer referência a fontes primárias em toda citação deste acontecimento, seja em obras acadêmicas ou populares. Uma busca eletrônica por qualquer tentativa de tradução reversa para o alemão na edição crítica Weimar também não dá qualquer resultado para este caso. LUTHER, Martin. D. Martin Luthers Werke. 120 vols. Weimar, 1883-2009. CD-ROM: ISBN 0-85964-4642. Muito possivelmente, esta é uma história apócrifa, mantida aqui apenas pelo seu potencial ilustrativo.

${ }^{2}$ LANGHOLM, Odd. The Legacy of Scholasticism in Economic Thought: Antecedents of Choice and Power. New York: Cambridge University Press, 1998, p. 119. ao longo da história do mundo, nas mais variadas correntes do cristianismo, e sempre retorna com a questão da justiça salarial. Para Timothy Keller, a pobreza vem de "salários baixos injustificáveis" de Bispos Católicos, em 1980, redigiu uma carta pastoral que foi publicada em forma de livro como Justiça econômica para todos. Dizem: "A prioridade mais urgente para a politica econômica doméstica é a criação de novos postos de trabalho com remuneração adequada" 4 . O padre Júlio Meinvielle escreveu: "Acima de tudo, deve-se recordar que o direito dos trabalhadores a salários justos é um dos direitos mais sagrados" 5 . A Encíclica Rerum Novarum traz: "entre os deveres principais do patrão, é necessário colocar, em primeiro lugar, o de dar a cada um o salário que convém" ${ }^{\prime \prime}$. Santo Antonino de Florença (1389-1459) dizia que "era tanto injusto quanto pecaminoso pagar menos do que o salário justo porque o trabalhador tinha bocas a alimentar tal como era injusto pagar menos do que o preço justo por causa da necessidade urgente do vendedor"7.

O que definiria, então, a justiça de uma precificação $0^{8}$ salarial? A visão comum é que o

${ }^{3}$ KELLER, Timothy. Justiça Generosa: A graça de Deus e a justiça social. São Paulo: Vida Nova, 2013, p. 50.

${ }^{4}$ Economic justice for all. Washington: USCC, 1986, p. 69.

${ }^{5}$ Concepción Católica de la Economía. Buenos Aires: Cursos de Cultura Católica, 1936, p. 29.

${ }^{6}$ Encíclica Rerum Novarum (Das Coisas Novas), escrita pelo Papa Leão XIII (1810-1903) em 1891. As principais encíclicas católicas que tratam de relações trabalhistas são Rerum Novarum (1891), Quadragesimo Anno (1931), Laborem Exercens (1981) e Centesimus Annus (1991).

${ }^{7}$ Summa Theologica moralis.1477, Part II, tit. I, cap. 17, n. 8.

${ }^{8}$ É economicamente bem estabelecido que salário é também um preço, e por isso tratamos os dois juntos aqui. O salário é o preço de um serviço prestado, de uma habilidade posta em uso para fim específico. Meu salário é o preço de mercado do meu trabalho. São Bernardino já dizia que as mesmas regras econômicas que são aplicadas aos preços devem ser aplicadas aos salários, que chama de pretium obsequiorum ("De 
saláriojustoé o salário que possui determinado valor aceitável à vida do trabalhador. Adolfo Lindenberg segue o espírito da Doutrina Social da Igreja Católica Apostólica Romana ao defender que

os salários a pagar deveriam ser justos e ter um valor tal que permitisse aos trabalhadores sustentar as duas famílias em condições adequadas. Significa isto que os ganhos deveriam tender a atingir um nível conforme à dignidade da natureza humana, ou seja, em condições normais deveriam ser suficientes para permitir que os assalariados, a trabalhar um número de horas semanais considerando razoável para a formação de um pecúlio, pudessem desfrutar de algum tempo de lazer, que as duas mulheres pudessem ficar em casa enquanto os filhos são pequenos, e que conseguissem pagar os seguros de saúde e as contribuições para a segurança nacional ${ }^{9}$.

Para muitos dos pensadores cristãos que trabalham a temática do preço justo, há um relacionamento direto entre valor financeiro e justiça do salário. No entanto, como se atribuiria valor moral às equivalências monetárias que indivíduos fazem com determinados serviços ou produtos? Falar de "salário injusto" em termos de resultado não seria tão absurdo quanto falar de "cor injusta", ou seja, atribuir moralidade ao que é amoral? Assim

Evangelio aeterno", sermão 35, art. 2, cap. 2-3, In: SIENA, Bernardino de. Opera omnia (volume 4). Florence, 1950-1963, p. 198). O problema do salário justo era considerado pelos escolásticos, incluindo Santo Antônio, como um apêndice ao problema do preço justo (cf. PFISTER, August. Die Wirtschaftsethik Antoninus von Florenz. Fribourg, Switzerland, 1946, p. 82). Até mesmo Karl Marx (1818-1883) concordaria, quando disse após citar Thomas Hobbes (1588-1679): "podemos determinar o valor do trabalho, como o de todas as outras mercadorias" (MARX, Karl. "Salário, preço e lucro", In: Manuscritos econômicos-filosóficos e outros textos escolhidos. São Paulo: Abril Cultural, 1978 , p. 80).

${ }^{9}$ LINDENBERG, Adolpho. O mercado livre numa sociedade cristã. Porto: Livraria Civilização Editora, 1999, p. 274-275. como a natureza não pode ser considerada justa ou injusta, os valores finais, frutos da negociação entre vendedor e comprador, ou patrão e empregado, não podem ser medidos em termos de justiça. É razoável questionar se pintar a parede da sala de cores vibrantes é justo ou injusto? Claro que os moradores terão suas preferências, e quem prefira cores leves pode argumentar que nunca aceitaria uma parede de cor extravagante, mas não há como debater o resultado em termos de "justiça", mas apenas os processos.

\section{II - Uma Teologia da Justiça}

Desde pelo menos o fim do século XIX, os intérpretes bíblicos têm definido "justiça" fundamentalmente como "fidelidade de Deus à alianç $a^{\prime \prime 10}$. Ou seja, Deus é justo porque age de acordo com as promessas pactuais que fez a Abraão, Davi e outros. De forma mais genérica, Deus é justo porque cumpre o que prometeu. Nota-se o aspecto social/interacional do conceito de justiça; ou seja, só se é justo ou injusto para com alguém e nunca para com alguma coisa. A palavra hebraica para Justiça (קָָּ tzedek) é essencialmente relacional, falando de algo que envolve dois seres, não se referindo à relação entre uma ideia e um objeto ${ }^{11}$.

Os conceitos de justiça e retribuição são bem marcantes em muitos textos do

${ }^{10}$ Essa definição tem sido contestada por grandes eruditos de hoje, principalmente na tentativa de vencer os exageros da Nova Perspectiva em Paulo. John Piper, por exemplo, define a justiça de Deus como seu compromisso absoluto em fazer o que é certo, sustentando o valor de sua glória (O futuro da justificação: uma resposta a N. T. Wright. Niterói, RJ: Tempo de Colheita, 2010, p. 211). Agir de forma justa, portanto, seria agir de forma correta em relação à glória de Deus. Esta definição piperiana é relativamente vaga, para não dizer imprecisa. Mesmo assim, ainda que Piper estivesse certo, ele mesmo assume que a fidelidade ao pacto estabelecido é um dos atos da justiça divina que ajuda a defini-la (Idem. Ibidem, p. 77).

${ }^{11}$ VON RAD, Gerhard. Teologia do Antigo Testamento. São Paulo: ASTE/TARGUMIM, 2006, p. 359-372. 
Pentateuco dentro de contextos sociais/ interacionais ${ }^{12}$. No Salmo 89, por exemplo, a justiça divina está relacionada à fidelidade de Deus em cumprir sua aliança com Davi. Através do paralelismo hebraico ${ }^{13}$, nos primeiros cinco versos, a fidelidade de Deus diz respeito ao cumprimento da aliança:

[...] com minha boca anunciarei a tua fidelidade por todas as gerações. [...] Firmaste nos céus a tua fidelidade. Tu disseste: "Fiz aliança com o meu escolhido, jurei ao meu servo Davi [...]". Os céus louvam as tuas maravilhas, Senhor, e a tua fidelidade na assembleia dos santos ${ }^{14}$.

Portanto, a justiça de Deus é relacionada também ao cumprimento da aliança, e tratada em paralelo com sua fidelidade.

A retidão e a justiça são os alicerces do teu trono; [...] alegram-se na tua retidão, [...] e a minha aliança com elejamais se quebrará. [...] Jamais desistirei da minha fidelidade. Não violarei a minha aliança nem modificarei as promessas dos meus lábios ${ }^{15}$.

A mesma relação surge em outros salmos, como: "O Senhor [...] revelou a sua justiça às nações. Ele se lembrou do seu amor leal ${ }^{16}$ e da sua fidelidade para com a casa de Israel" 17. "Não ocultei no coração a tua justiça; proclamei a tua fidelidade"18 e "responde-me por tua fidelidade

\footnotetext{
${ }^{12}$ Levítico 19.35-20.27.

${ }^{13} \mathrm{O}$ paralelismo hebraico é um método poético onde um conceito é definido a partir de estabelecer um paralelo com outro conceito sinônimo. A poesia hebraica não possuía rimas, mas elementos de sonoridade e de paralelo conceitual. Quando justiça e fidelidade à aliança aparecem em versos paralelos, isso significa que há aí uma equiparação dos conceitos.
}

${ }^{14}$ Salmos 89.1-5.

${ }^{15}$ Salmos 89.14,16,28,33-34.

16 "Amor leal" é o termo para a palavra hesed [דסח], que está em contextos de aliança (e.g, Davi e Jônatas; Rute e Noemi). Ou seja, está em situações de contratos, alianças entre indivíduos.

${ }^{17}$ Salmo 98.2-3.

${ }^{18}$ Salmo 40.11. e por tua justiça"19. No livro de Neemias, que tem como pano de fundo a relação de bênçãos e maldições da aliança mosaica, lemos: “Em tudo o que nos aconteceu foste justo; agiste com lealdade mesmo quando fomos infiéis" ${ }^{\prime 2}$. Nestes textos, "justiça" e "fidelidade à aliança" estão intimamente relacionados.

Desta forma, algo "justo" é fundamentalmente algo que aconteceu de acordo com regras e padrões corretos, mais do que algo que alcançou um determinado resultado específico; em outras palavras, a justiça é algo mais procedimental que teleológico. A oração do salmista foi: "Concede ao rei, ó Deus, os teus juízos e a tua justiça, ao filho do rei. Julgue ele com justiça o teu povo e os teus aflitos, com equidade" ${ }^{21}$. Para Davi, julgar com justiça significa julgar com equidade os aflitos, aplicando a lei de forma igual a todos os homens. Um jogo de futebol foi justo se o juiz seguiu corretamente as regras do esporte, se os bandeirinhas marcaram corretamente os impedimentos e nenhum jogador foi comprado para dar a vitória à outra equipe. Não importa quem ganhe a partida: se tais regras foram seguidas, se tal processo foi respeitado, então tivemos um jogo justo. Da mesma forma, se os juízes marcam pênaltis fora da área, se os bandeirinhas deixam passar impedimentos e o jogador principal da seleção foi subornado para não se dedicar tanto ao jogo, não importa o resultado final da partida: podemos dizer que o resultado foi injusto, já que não houve justiça nos processos.

Essa percepção do significado de justiça, no entanto, tem mudado ao longo do tempo. Thomas Sowell, em The Quest for Cosmic Justice, chama atenção para as modificações modernas na conceituação e no uso da palavra "justiça". Tradicionalmente, justiça ou injustiça são compreendidas como características de um processo. Independentemente do resultado do julgamento, podemos dizer que justiça

\footnotetext{
${ }^{19}$ Salmo 143.1; 71.2 .

${ }^{20}$ Neemias 9.33 .

${ }^{21}$ Salmo 72.1-2.
} 
foi feita se o julgamento aconteceu com respeito às leis, com um juiz imparcial e jurados comprometidos com a verdade. $\mathrm{O}$ mesmo acontece com as lutas esportivas. Dizemos que houve uma luta justa quando ambos os lados seguem as regras do combate, ninguém descumpre as regras antidopping e ninguém cede a vitória em troca de suborno, independente do resultado do combate. A justiça é tradicionalmente percebida como a atuação imparcial de um processo, e não como a obtenção de certos resultados determinados ${ }^{22}$.

No segundo capítulo da carta de Paulo aos Romanos, a justiça de Deus é definida em termo de julgamentos que se dão de forma imparcial, com processos justos, sem criar parcialidades entre judeus e gentios. Diz que "o juízo de Deus [...] é conforme a verdade" ${ }^{23}$ e um "justo julgamento" 24, uma vez que "em Deus não há parcialidade" ${ }^{25}$. A justiça do julgamento divino é estabelecida por ser verdadeira e imparcial. É por isso que, para Paulo, "no evangelho é revelada a justiça de Deus" ${ }^{26}$, ou seja, o modo correto de Deus se manifestar em seus processos. Uma vez que Deus "havia deixado impunes os pecados anteriormente cometidos" ${ }^{27}$ no Antigo Testamento, sem condenar aqueles que se arrependeram, uma acusação de injustiça em seus julgamentos poderia recair sobre Deus. A justiça de Deus é revelada, então, na punição substitutiva de Cristo, provando que o julgamento de Deus não é parcial: "mas, no presente, demonstrou a sua justiça, a fim de ser justo e justificador daquele que tem fé em Jesus" 28 . Deus é justo em justificar pecadores porque puniu seu Filho em nosso lugar.

22 SOWELL, Thomas. The quest for cosmic justice. New York, NY: Touchstone, 2002, p. 8-9.

\footnotetext{
${ }^{23}$ Romanos 2.2.

${ }^{24}$ Romanos 2.5.

${ }^{25}$ Romanos 2.11 .

${ }^{26}$ Romanos 1.17 .

${ }^{27}$ Romanos 3.25 .

${ }^{28}$ Romanos 3.26 .
}

A teologia bíblica da retribuição do Antigo Testamento está atrelada ao que se faz ou não dentro dos parâmetros estabelecidos pela lei mosaica ${ }^{29}$, ou seja, numa aliança. Os padrões do relacionamento com Deus foram estabelecidos e a justiça para com o Senhor está baseada em andar de acordo com o "contrato divino". Notamos em Apocalipse que Deus retribui a cada um segundo as suas obras. As obras são levadas em consideração quando da aceitação ou não de Jesus como o Messias. No caso da salvação, Deus, por ser o criador, é quem estipula as condições para a vida eterna de forma unilateral, a saber, a fé somente em Jesus pela graça.

Low e Nida seguem esta perspectiva quando definem "justiça" (no grego,

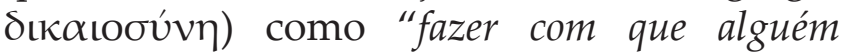
esteja num relacionamento adequado ou correto com outra pessoa - 'colocar num relacionamento correto'"', em contraposição a uma perspectiva meramente forense de $\delta \iota \kappa \alpha \iota o ́ \omega, \delta \iota \kappa \alpha i ́ \omega \sigma \iota \varsigma$ e

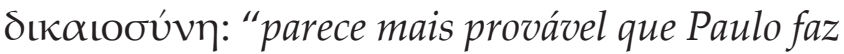
uso dessas expressões no contex to do relacionamento da aliança, e não no contexto de procedimentos jurídicos". Para alguns acadêmicos, ainda,

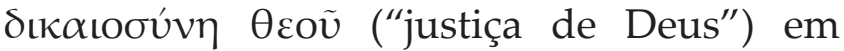
Romanos 1.17 seria uma referência à fidelidade de Deus às promessas feitas a Abraão ${ }^{30}$. Desta feita, a definição de "justiça" para Paulo e para o Antigo Testamento está atrelada ao contexto da aliança.

Esse modelo de justiça relacionalprocedimental, então, está relacionada com a justiça de Deus para com o homem e nos relacionamentos interpressoais, ou mesmo no relacionamento entre o homem e o ambiente. Mas este conceito de justiça seria aplicado às relações econômicas, especificamente nas relações salariais?

\footnotetext{
${ }^{29}$ Deuteronômio 28: bênção e maldição.

${ }^{30}$ LOUW, Johannes; NIDA, Eugene. Léxico GregoPortuguês do Novo Testamento baseado em domínios semânticos. São Paulo: Sociedade Bíblica do Brasil, 2013, p. 404.
} 
II.1 - A Parábola da Vinha: Como Jesus Aplica o Conceito Bíblico de Justiça nas Relações Salariais

A Parábola da Vinha ${ }^{31}$ só se encontra registrada no evangelho de Mateus. Isto é um ponto notável, logo de cara, por Mateus ter sido cobrador de impostos antes de ser chamado por Cristo. Ao que parece, uma vez que o autor dominava assuntos de ordem econômica por questões de ofício, usa seu arcabouço teórico na composição de seu registro inspirado. Não é à toa que Mateus trabalha muito a temática das riquezas e das posses em seu evangelho, além de nos fornecer informações sobre os ensinamentos de Jesus que tinham relacionamento com economia e mercado.

É no capítulo 20 do evangelho de Mateus, então, que Jesus conta a parábola sobre o proprietário de uma vinha que saiu de manhã cedo para contratar trabalhadores. Encontrando alguns, combinou que o dia de trabalho valeria um denário (o valor pago normalmente por um dia de trabalho braçal) e os mandou para a sua vinha. Passado algum tempo, já por volta

\footnotetext{
${ }^{31}$ Ver Mateus 20.1-15. Essa parábola está inserida na macroestrutura do capítulo 19.16-20.16, onde o jovem rico pergunta como alcançar a vida eterna e Jesus o leva a ponderar na sua confiança nas riquezas. Os discípulos se espantam: se um rico não consegue entrar no reino, o que dizer deles, homens pobres? Jesus afirma que é uma obra somente para Deus (cf. 19.26). O relato se segue com a afirmação de que os últimos serão os primeiros. Pelo contexto, os primeiros se revelam na pessoa do jovem rico (ou seja, todo aquele que é rico ou que pensa ter alguma vantagem para entrar e garantir a vida eterna), que, aos olhos dos discípulos, teria uma vaga no céu. Os últimos são os discípulos que, sem vantagem alguma, não têm garantias por si mesmos de conquistar o reino, a não ser crendo na pessoa de Jesus. A temática dos últimos e primeiros é desenvolvida pela parábola da vinha. Um senhor estabeleceu o preço do serviço. Chamou os primeiros trabalhadores e depois, já quase no fim do expediente, chama outros. Os que foram primeiros acharam que receberiam mais, uma vez que os últimos receberam um denário. Todavia, todos receberam a mesma quantidade. Um dos pontos centrais da parábola, portanto, é que quem estabelece os parâmetros para entrar no reino é o próprio dono do reino, tal qual o dono da vinha. A macroestrutura do texto corrobora nossas percepções.
}

das noves horas da manhã, o dono da vinha saiu e viu alguns homens na praça que não haviam encontrado trabalho para aquele dia. Convidando-os a trabalhar também em sua vinha por aquele dia, fez a seguinte promessa: "Vão também trabalhar na vinha, e eu lhes pagarei o que for justo" ${ }^{\prime 32}$. Havia a promessa de um salário justo por aquele dia de trabalho.

Todas as vezes que o dono da vinha saia, fazia a mesma coisa com quem encontrasse sem trabalho, chegando a contratar pessoas faltando apenas uma hora para encerrar o expediente. Ao cair da tarde, o dono da vinha disse ao responsável pelos pagamentos que chamasse os trabalhadores e lhes pagasse o salário estabelecido, começando com os últimos contratados, terminando com os primeiros. Vieram então aqueles que foram contratados por volta das cinco horas da tarde, e cada um recebeu um denário como pagamento. Quando os que tinham sido contratados primeiro viram aquilo, ficaram exultantes, pois pensaram: "Se quem foi contratado no fim do dia, recebeu um denário, então nós vamos receber ainda mais que isso!".

No entanto, para a surpresa e revolta deles, cada um recebeu também um denário. Quando o receberam, começaram a se queixar do proprietário da vinha. Usaram um argumento convincente e aparentemente justo: "Estes homens contratados por último trabalharam apenas uma hora, e senhor os igualou a nós, que suportamos o peso do trabalho e o calor do dia". Alguns estavam ganhando por hora trabalhada cerca de dez vezes o que outros estavam recebendo pelo mesmo trabalho! O dono da vinha, então, que havia prometido um salário justo àqueles trabalhadores, respondeu de forma precisa: "Amigo, não estou sendo injusto com você. Você não concordou em trabalhar por um denário? Receba o que é seu e vá. Eu quero dar ao que foi contratado por último o mesmo que the dei. Não tenho o direito de fazer o que quero com o meu dinheiro?" 33 .

\footnotetext{
${ }^{32}$ Mateus 20.4.

${ }^{33}$ Mateus 20.13-15.
} 
Quando o dono da vinha diz que não está sendo injusto ${ }^{34}$, remete ao início do texto e sua promessa de um "salário justo". Para o dono da vinha, não havia qualquer injustiça sendo cometida - ou seja, o trato de pagar um salário justo havia sido cumprido, uma vez que o acordo combinado estava sendo cumprindo. Ainda que uns estivessem recebendo até dez vezes mais que outros trabalhadores por hora trabalhada, a justiça no pagamento estava relacionada ao contrato anteriormente estabelecido.

Diante disto, a Parábola da Vinha se apresenta em total acordo com a relação veterotestamentária entre a justiça e a fidelidade a uma aliança anteriormente estabelecida. Havia um contrato, um pacto, anteriormente estabelecido entre empregado e empregador. A justiça da relação salarial se daria com o contratado entregando o serviço que concordou em fornecer, e o patrão entregando o salário ou qualquer outro benefício que tenha concordado em fornecer. A fidelidade aos contratos, ao pacto trabalhista estabelecido, é o que estabelece a justiça da relação econômica entre indivíduos. Em resumo, podemos dizer que o preço justo é o preço de mercado ${ }^{35}$. O salário justo é o

${ }^{34}$ Note que Jesus está enfatizando que os últimos receberam um denário por graça. A questão não é que Jesus foi injusto com os primeiros trabalhadores; antes, que foi gracioso para com os últimos. A graça manifesta a alguns não invalida sua justiça a outros.

${ }^{35} \mathrm{Há}$ quem argumente que a ideia de justiça salarial que o texto aponta é uma substancialmente diferente da sustentada aqui. O motivo para isso é que, sendo toda a parábola sustentada a partir da quebra de expectativa, o ponto da passagem é justamente a alteridade entre o modo de agir de Deus e o modo de agir do homem, de forma que o modo como o patrão age na parábola não pode ser considerado indicativo de um salário humano justo, uma vez que é o modo próprio de Deus agir e não o do homem. Assim, ficaria implícito que o salário justo entre os homens é aquilo que o patrão da parábola não faz. Esta argumentação acaba não se sustentando com facilidade. Quando acusado de não pagar um salário justo, a resposta do dono da vinha é: "Você não concordou em trabalhar por um denário? [...] Não tenho o direito de fazer o que quero com o meu dinheiro?". Há dois movimentos argumentativos aqui. $\mathrm{O}$ primeiro salário que você aceita receber. O lucro justo é o que você consegue no mercado sem uso de fraudes ou ilegalidades. Você pode dizer " $\mathrm{Eu}$ ganho pouco!" ou "Isso está muito caro!", mas não "Meu salário é injusto!" ou "Este preço é uma injustiça!", a menos que haja fraude, coação ou quebra de contratos ${ }^{36}$.

É muito possível considerar que uma parte de um contrato pode estar em desvantagem. Por exemplo, se há um excesso no mercado de trabalho, a lei da oferta e da procura empurra os salários para baixo. Dependendo

está relacionado à questão da justiça, o segundo à questão da graciosidade. Se a graça é respondida em termos a liberdade de fazer o que se quer com o que é seu, a questão da justiça é respondida em termos de fidelidade ao contrato. Não há aqui qualquer indicação de que o dono da vinha não pagou um salário justo, mas sim que a justiça foi satisfeita na fidelidade ao que foi combinado anteriormente e na autonomia do patrão de ser ou não gracioso para além do contrato. A comparação é justamente positiva. O patrão foi justo em ser fiel ao contrato, e gracioso em ir além dele. Deus é o patrão gracioso que dá salvação e reino aos pobres sem deixar de ser justo na fidelidade às suas alianças.

${ }^{36}$ As parábolas são usualmente comparações positivas. Aquilo que é usado na parábola como ilustração para algo positivo é usualmente de ordem positiva, assim como aquilo que é usado para ilustrar algo negativo é usualmente algo de moralidade transviada. Linguisticamente, não é factível imaginar Jesus compondo uma estrutura parabólica comparando o Reino dos céus a uma prostituta que recebe muitos amantes, ou a oração a alguém que paga propina a um burocrata desonesto. Desta feita, sabendo que o dono da vinha ilustra o próprio Deus, é de se esperar que o ponto levantado seja um common ground de algo moralmente bom. A parábola trata a justiça das relações salariais em termo de cumprimento de contrato, e isso é tratado de forma positiva. Ainda que haja comparações não-parabólicas de ordem negativa, como em Lucas 12.39, onde a vinda do ladrão é usada para ilustrar a vinda inesperada de Jesus, as construções parabólicas são usualmente comparações positivas, onde coisas boas são comparadas com coisas boas e coisas más são comparadas com coisas más. Em poucas parábolas Jesus usa práticas morais questionáveis para ilustrar pontos positivos da fé, mas sempre o faz indicando seu interesse de mostrar que se até os ímpios agem de determinada forma positiva em suas maldades, quanto mais Deus ou o cristão. Isso é o que aparece na parábola da viúva e do juiz (Lucas 18.2-5) e do administrador desonesto (Lucas 16.1-8). 
da situação econômica, muitos poderiam ser compelidos a trabalhar por salários que mal lhes garantiriam a sobrevivência. Não estamos argumentando que o mercado é à prova de dificuldades reais. Nosso ponto é que a solução para estes problemas não está em um controle governamental de preços, mas em liberdade sindical (sem envolvimento político-governamental), liberdade de empreendimento, concorrência, desburocratização, caridade, etc. Adolpho Lindenberg, em O mercado livre numa sociedade cristã, argumenta neste sentido:

Constitui um objectivo louvável que os salários sejam compatíveis com a dignidade humana, mas, em princípio, deverá alcançar-se tal objectivo mediante os mecanismos naturais da economia, incluindo um grau adequado de autonomia salarial. A comprovar a validade desta posição estão os salários normalmente elevados nos países que adoptaram a economia de mercado. O que todos os países asiáticos, como por exemplo Taiwan, Coreia do Sul, Singapura, Indonésia e Tailândia tiveram de fazer foi abrir as suas economias à iniciativa privada; os salários miseráveis predominantes até então melhoraram significativamente ${ }^{37}$.

Um preço ou um salário justo são basicamente preços e salários que foram definidos a partir de processos corretos ejustos. Não podemos falar de justiça e injustiça em termos de resultado financeiro, simplesmente, mas do processo para a definição salarial. $\mathrm{Na}$ parábola da vinha, a justiça do pagamento estava relacionada ao estabelecimento dos contratos. É um salário justo aquele que está de acordo com o combinado entre as partes, onde ninguém foi enganado ou coagido a adentrar naquela relação trabalhista. É um preço justo aquele que foi combinado entre as partes, onde não há fraude ou falsificações. Independentemente do preço ou do salário, sejam altos ou baixos, há justiça quando o processo se dá corretamente ${ }^{38}$.

${ }^{37}$ LINDENBERG. O mercado livre numa sociedade cristã, p. 278.

${ }^{38} \mathrm{Se}$ um preço ou salário justo se manifesta nas
Muitos cristãos, assumindo sem saber um modelo marxista de valor-trabalho, acreditam que os salários serão justos se corresponderem ao esforço que foi empregado pelo trabalhador, uma vez que é o trabalho empregado em algo que dá valor àquilo. Esta percepção, no entanto, está longe de representar uma forma madura de compreender o valor das coisas. Se eu empregasse, por exemplo, um esforço imenso para produzir um buraco no meu quintal, mas encontrasse um diamante na calçada de casa, eu venderia o diamante muito mais caro do que eu venderia um buraco, embora o esforço para cavar fundo seja bem maior que o esforço de catar algo precioso do chão. O que dá valor a algo não é o trabalho empregado para construílo, mas sim o quanto aquilo é valorizado pelos potenciais interessados. Legisladores medievais postulavam que um bem vale o quanto as pessoas estão dispostas a pagar por ele ("tantum valet res, quantum vendi potest"39). Muitas pessoas acreditam que possuem um

coisas acontecendo da forma correta, de acordo com os preceitos contratuais pré-estabelecidos, isso inclui o próprio cumprimento das leis vigentes. Muitos empresários, lutando contra as inúmeras regulamentações que lhes atrapalham e encarecem seus serviços e produtos, acabam usando de subterfúgios ilegais como uma maneira de se beneficiar das próprias regulamentações. É comum empresas venderem produtos por preços abaixo do que é permitido por lei a fim de quebrar o concorrente. Certos produtos para animais estão na categoria de "remédio", o que possui preços regulamentados com mais força que outros produtos comuns. Farmácias propriamente ditas e outras empresas possuem regulamentações mais fortes, e quebram a lei a fim de aplicar preços mais baixos - o que beneficia os compradores por um momento, mas age com injustiça com outros concorrentes que não desejam quebrar a lei a fim de permanecer no mercado. A regulamentação é ruim, mas usá-la como um instrumento a seu favor também é desonesto. Muitas pequenas lojas de roupas faliram em Fortaleza com a potencialização do comércio informal de vestuário na região praiana, já que não precisavam de nota fiscal. As regras, mesmo ruins, devem valer para todos, à revelia do sofrimento do justo. Isso não significa que vácuos legislativos não possam ser usados para a promoção de concorrência, como acontece com o Uber.

${ }^{39}$ OLIVI, Pietro. Tractatus de emptionibus et venditionibus, de usuris, de restitutionibus, 51 . 
salário injusto porque trabalham muito. Como trabalham muito e ganham pouco, acham injusto o valor que recebem. No entanto, muitas pessoas trabalham muito, mas geram pouco valor para o mercado. O trabalho de um professor deve ser muito maior que o de um jogador de futebol, mas as pessoas estão mais dispostas a pagar caro pelo jogo que pela educação. Em nossa sociedade, que valoriza mais o entretenimento que o estudo, o valor de mercado gerado pelo jogador de futebol é superior ao do professor, e por isso o primeiro ganha muito mais. $\mathrm{O}$ salário não diz respeito ao quanto você trabalha, mas sim ao quanto de valor você gera aos olhos da sociedade ${ }^{40}$.

Há quem argumente que o preço de equilíbrio ("ótimo de Pareto") seja aquilo que o governo deve tentar emular em busca de encontrar justiça nos preços. Mas esse argumento desconsidera que os dados de mercado que são lidos pelo governo na tentativa de analisar qual seria seu ponto de equilíbrio não são os mesmos dados do momento posterior, de forma que o ponto de equilíbrio que o governo calcula já não se aplica mais ao mercado do momento do cálculo. Para Salerno, o sistema de preços não é "um mecanismo para economizar e comunicar o conhecimento relevante para os planos de produção", uma vez que os "preços correntes são preços já concretizados" que "correspondem a uma constelação de dados econômicos que já se concretizaram" ${ }^{41}$.

\footnotetext{
${ }^{40}$ É preciso pontuar o quanto é triste que nossa sociedade seja doente o suficiente para valorizar mais um Neymar que um professor universitário. A injustiça aí não está no mercado, mas sim nos corações dos indivíduos, que possuem valorações tolas. A correção da tolice econômica, no entanto, não se dá através de algum tipo de controle de preços, mas de formação cultural e transformação espiritual.

${ }^{41}$ SALERNO, Joseph T. Ludwig von Mises as Social Rationalist. The Review of Austrian Economics, Vol. 4 (1990), p. 44.
}

\section{II.2 - Timothy Keller e as Bases Bíblicas do Preço Injusto}

O pregador americano Timothy Keller, autor premiado e muito conhecido no Brasil e no mundo, tem sido um autor de grande vulto de obras relacionadas com trabalho e justiça social. Em seus livros, costuma usar certas bases bíblicas para lidar com a questão do preço justo. No livro Ministérios de Misericórdia, argumenta que uma das causas da pobreza são os "salários [...] injustamente baixos (Ef 6.8,9)" 42 . Mais à frente, na mesma obra, fala de empresas que pagam "salários e benefícios injustamente baixos (Jr 22.13)" 43 . Semelhantemente, em Justiça Generosa, fala de "salários baixos injustificáveis ( Jr 22.13; $\operatorname{Tg}$ 5.1-6)" 4 . Jeremias 22.13, Efésios 6.8,9 e Tiago 5.1-6 são os três textos que Keller apresenta para falar de precificações salariais injustas com referência a salários baixos. O que estes textos expõem de verdade?

Jeremias 22 traz a mensagem do Senhor para Salum, rei de Judá, sucessor de seu pai Josias. A condenação profética está em ter construído um palácio sem pagar seus empregados ${ }^{45}$. Diz o texto: "Ai daquele que constrói o seu palácio por meios corruptos, seus aposentos, pela injustiça, fazendo os seus compatriotas trabalharem por nada, sem pagarlhes o devido salário" ${ }^{46}$. O Senhor estaria condenando o rei por meio do profeta por não ter pago o salário aos operários, sem

${ }^{42}$ KELLER, Timothy. Ministérios de misericórdia: $\mathbf{O}$ chamado para a estrada de Jericó. São Paulo: Vida Nova, 2016, p. 118.

${ }^{43}$ Idem. Ibidem, p. 199.

${ }^{44}$ KELLER. Justiça Generosa: A graça de Deus e a justiça social, p. 50. Este trecho de Justiça Generosa é citado por Antônio Carlos Costa como base para o problema da pobreza (COSTA, Antônio Carlos. Convulsão Protestante: Quando a teologia foge do templo e abraça a rua. São Paulo: Mundo Cristão: 2015, p. 62).

${ }^{45}$ SICRE, José Luís. Com os pobres da terra: a justiça social nos profetas de Israel. Santo André, SP: Academia Cristã/Paulus, 2015, p. 29, 571.

${ }^{46}$ Jeremias 22.13. 